\title{
Geoheritage Conservation of Paleontological Sites in Aring Area, Gua Musang District, Kelantan, Malaysia
}

\author{
Dony Adriansyah Nazaruddin ${ }^{1 *}$, Ahmad Rosli Othman ${ }^{2}$ \\ ${ }^{1}$ Geoscience Programme, Faculty of Earth Science, Universiti Malaysia Kelantan (UMK) Jeli Campus, Kelantan, Malaysia \\ E-mail:*dony@umk.edu.my
}

${ }^{2}$ Department of Minerals and Geoscience Malaysia Kelantan, , Kelantan, Malaysia

\begin{abstract}
Many small invertebrate fossils have been recently discovered in two locations in Aring area, Gua Musang district, Kelantan, Malaysia. The fossils found in the area have been identified based on the previous studies. A joint effort of Universiti Malaysia Kelantan and the Depertment of Minerals and Geoscience Malaysia Kelantan has been initiated to conserve the fossils and paleontological sites as geoheritage resources in the state of Kelantan. Field works have been conducted to observe the recent situation and to identify the threats to the fossil sites. Some literatures have been reviewed to study the examples of the conservation of fossils and fossil sites in some other coutries. This paper will expose fossil occurrences in the study area and discuss some threats to these fossil sites. In addition, this study will also propose an idea to conserve these sites by setting up a paleontological field museum in the vicinity of Aring.
\end{abstract}

Keywords-Geoheritage; conservation; paleontological site; fossils; Aring area; Gua Musang district.

\section{INTRODUCTION}

Numerous small-sized marine invertebrate fossils have been discovered in two locations in Aring area (named for the purpose of this study as "Fossil Site-1" and "Fossil Site2 "). Aring is a plantation area located in Gua Musang district, in southern part of the state of Kelantan, Malaysia (Figure 1). The discovery has started in 2008 when a constructional work has been conducted to open a new road from Gua Musang town (in Kelantan) to Kuala Berang (in the neighbouring state of Terengganu) by cutting the hills in the area (Figure 2). Some of the earliest reports of fossils in the area were on phylum mollusc such as ammonoids, bivalves, and gastropods, and on phylum brachiopods (Ahmad Rosli \& Mohd Shafeea, 2008; Ahmad Rosli \& Mohd Shafeea, 2009; Ahmad Rosli \& Mohd Shafeea, 2010; Ahmad Rosli, 2010). These fossils play important roles (index fossils) in determining the age of the marine Triassic rock fromations in Peninsular Malaysia. This area is also well known as the most abundant Triassic fossils within the Central Belt in Peninsular Malaysia.

Fossils are one of valuable geological resources which serve as important keys for learning about the ancient environment, determining the age of strata and studying the past history of the Earth. In Aring area, although these fossils can be considered as part of geological heritage, they are facing some threats.

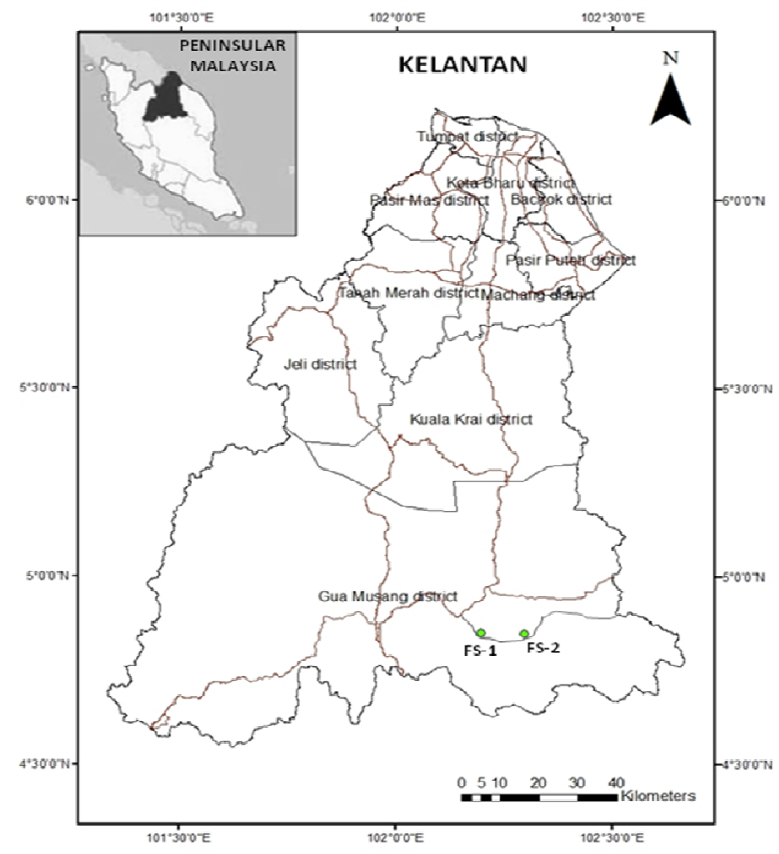

Fig. 1 Fossil sites in Aring area, Gua Musang district of southern Kelantan, Malaysia (indicated by "FS-1" for Fossil Site-1 and "FS-2" for Fossil Site-2). 
The sites are also not managed well after the constructional works. To protect these fossils and fossil sites, and to increase awareness of the importance of them, Universiti Malaysia Kelantan (UMK) with the collaboration of the Depertment of Minerals and Geoscience Malaysia Kelantan (JMG Kelantan) will initiate a proper way to conserve these fossils and fossil sites. In this paper, after a brief overview of geology of the study area and a brief explanation on fossil sites and fossil records in the study area, we will describe some threats to these fossil sites and discuss a proposed paleontological field museum and its importance for paleontology and conservation, and discuss what the future may hold.

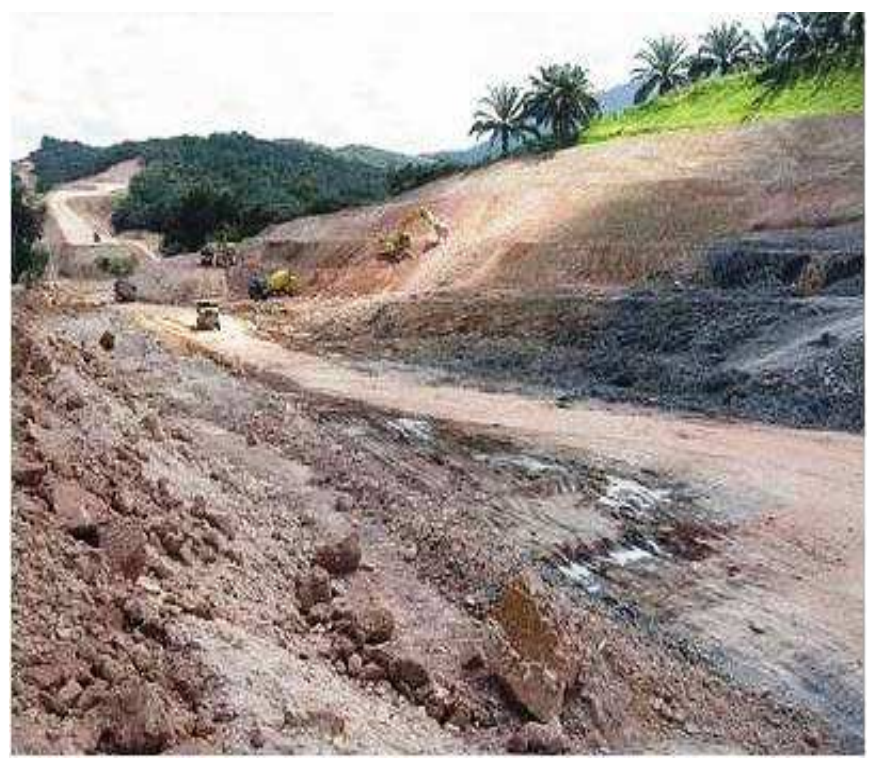

Fig. 2 Panoramic view of Aring area showing the construction work of the new road connecting Gua Musang town and Kuala Berang since 2008 to 2010. These works have exposed the fresh outcrops of sedimentary rock layers. Some layers contain important Triassic fossils. The recent situation shows this road has now turned to an excellent highway, however the fossilcontaining outcrops still can be observed.

\section{General GeOlOGy Of ARING AREA}

Kamal Roslan (2006) divided the southern Kelantan stratigraphically into four areas: Kuala Betis, Gua Musang, Aring and Gunung Gagau. The study area is located in Aring area, within the Central Belt of Peninsular Malaysia. Because of their similarity in lithology and age, it is believed that rock units in Aring area are considerably part of Gua Musang Group (Figure 3). Aw (1990) has mapped four rock units in Aring area, namely Aring Formation, Telong Formation, Nilam Marble Formation and Koh Formation (Figure 4). Their respective brief explanations are as follow:

\section{A. Aring Formation}

Aring Formation consists of dominantly pyroclastic sequences (tuff) along with thin layers of argillite and marble interbeds. Numerous fossils were reported by Aw (1990) such as Lower Carbon brachipods and fusulinids which are assumed as the oldest fossils in the Central Belt of Peninsular Malaysia.

\section{B. Telong Formation}

Based on the fossil records on pelecypods, ammonoids, gastropods and brachiopods, this formation is designated of the Upper Permian - Upper Triassic. The rock sequence of this formation mostly consists of argillite and marble with thin tuff and andesite. According to Zakaria Hussain et.al. (2008), the ammonoid assemblage is indicative of a Middle - Late Triassic age $(240$ - 220 million years ago $)$ and belonged to the Tethyan Province.

\section{Nilam Marble Formation}

This formation is composed of dominantly massive limestones/marbles with thin tuff and argillite interbeds. There are shell fossils (mostly fusulinids) within the limestones/marbles. Nilam marbles have two types based on the age range: Permian marble and Upper Triassic marble (Aw, 1990). These lens-shaped limestones/marbles are distributed separately within Aring Formation and Telong Formation.

\section{Koh Formation}

Koh Formation consists of sandstones (arenite and rudite), argillite and mudstone interbeds. This formation is Jurassic/Creataceous terrestrial sedimentary rocks. This formation is the youngest formation in Aring area.

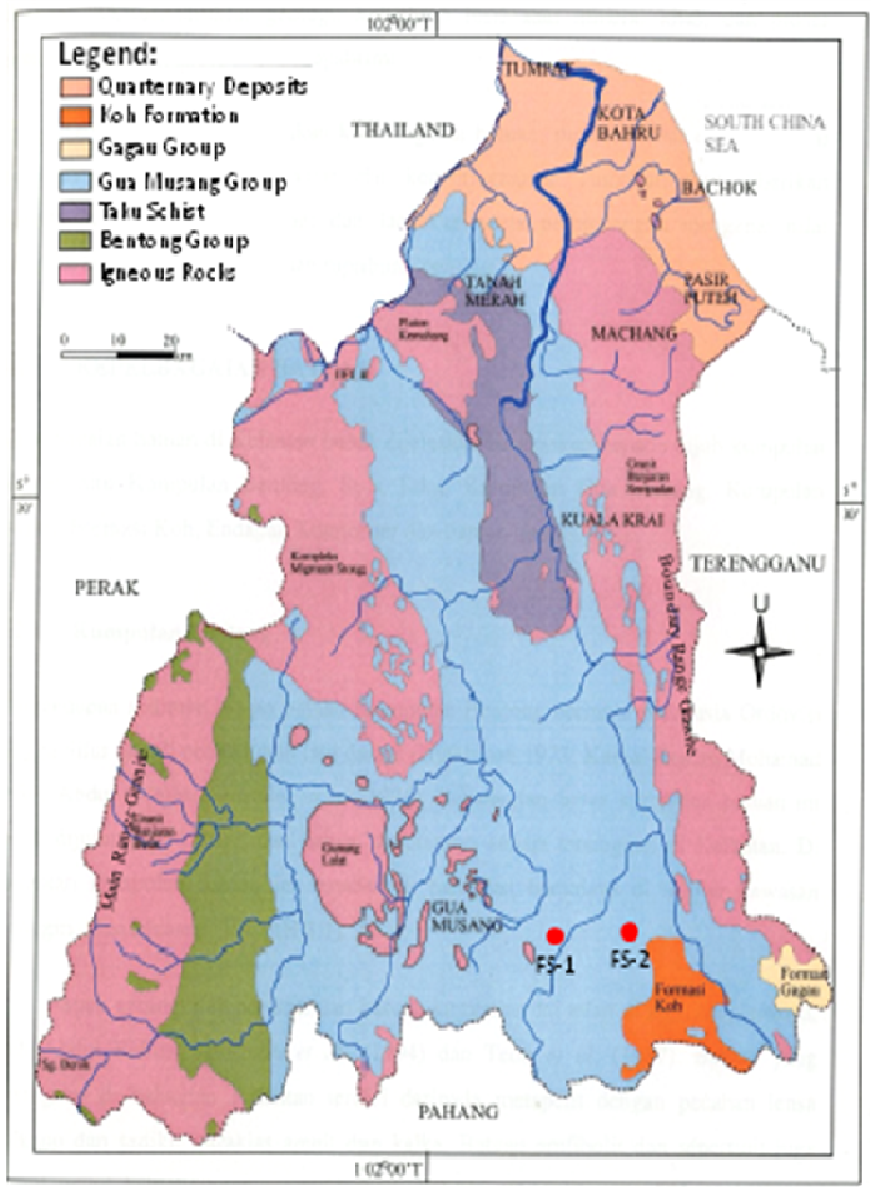

Fig. 3 General geology of Kelantan. The fossil sites (indicated by "FS-1" and "FS-2") are located in southern Kelantan and lithologically become part of Gua Musang Group. 


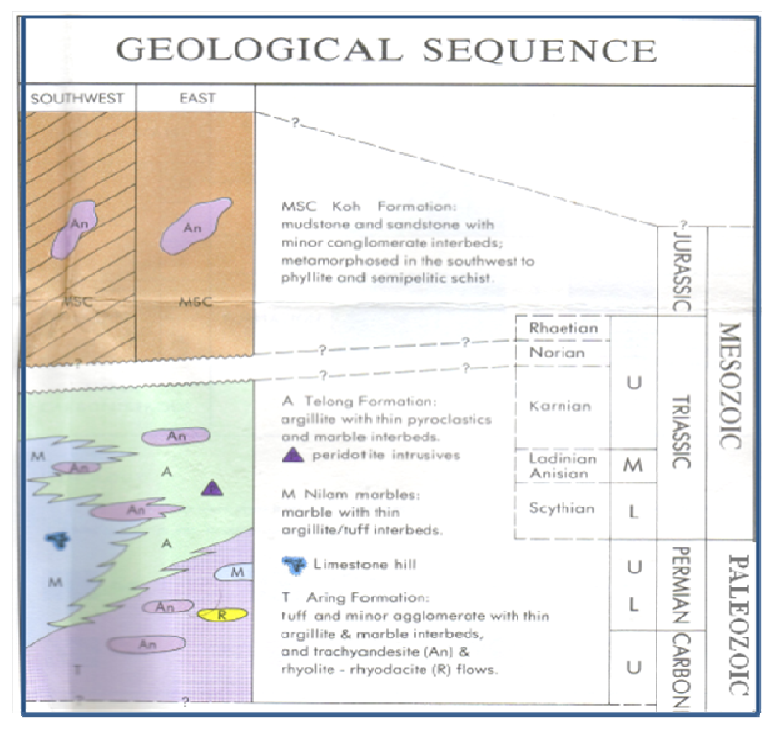

Fig. 4 Stratigraphical sequence of Aring area (Aw, 1990).

\section{FOSSIL SITES AND FOSSIL RECORDS OF ARING AREA: AN OVERVIEW}

According to Lee (1992), fossils are not a common occurrence in Malaysian rocks. Almost all fossils reported to date are of small invertebrates and plants as well as trace fossils of past animal activities. Vertebrate fossils are very rare and no dinosaur remain has been discovered to date although such fossils have been found in similar rocks in adjacent Thailand. The most common occurrence of fossils is within unmetamorphosed sedimentary rocks such as limestone, sandstone, siltstone and shale or mudstone which cover large parts of both East and West Malaysia.

Fossil sites in Aring area is located along the road connecting Gua Musang town and Kuala Berang. These sites are in the roadcuts within the plantation area of "Felda Aring 5 " in the district of Gua Musang, in southern Kelantan. Topography of this area is an undulating and hilly terrains. The local climate is tropical and characterized by monsoons. There are two locations of fossil sites in Aring, namely "Fossil Site-1" and "Fossil Site-2". These two localities contain mostly a diverse assemblage of phylum Mollusc fossils such as ammonoids, bivalves and gastropods. The fossils of the area have been identified from previous studies (Ahmad Rosli \& Mohd Shafeea, 2008; Ahmad Rosli \& Mohd Shafeea, 2009; Ahmad Rosli \& Mohd Shafeea, 2010; Ahmad Rosli, 2010).

\section{A. Fossil Site-1 (QZ467)}

This site is a fossil-containing outcrop which is situated in $\mathrm{N} 4^{0}$ 51'3.8", E $102^{0} 11$ ' 52" (Figure 5). This fresh outcrop were exposed after the hill cutting works. Fossil records from this site are mostly on phylum Mollusc, mainly ammonoids and bivalves. These fossils were found within thin layers of dark grey tuffaceous mudstone of Telong Formation. The mudstone was formed from mud deposited in a deep-water marine environment. This locality contain eight species of Lower Ladinian, Middle Triassic ammonoids i.e. Frankites regoledanus (Mojsisovics), Frankites apertus (Mojsisovics), Protrachyceras costulatum Mansuy, Joannites sp., Megaphyllites jarbas Mojsisovics,
Anolcites sp., Clionitites sp., Celtites epolensis Mojsisovics (Ahmad Rosli \& Mohd Shafeea, 2010; Figure 6). Bivalve fossils were found in this locality including of Posidonia kedahensis Kobayashi, Posidonia kedahensis Wissman and Daonella pahangensis Kobayashi (Ahmad Rosli, 2010).

\section{B. Fossil Site -2 (QZ480)}

This site is a fossil-containing outcrop of Middle Triassic sedimentary rocks, located around $10 \mathrm{~km}$ from Fossil Site-1 to the east, in the coordinate of $4^{0} 50$ '52.6", E $102^{0} 17$, 51.9" (Figure 7). Fossils of Mollusc (ammonoids, bivalves and gastropods) and brachipods are some fossil records from this site. This locality contains five ammonoid species i.e. Balatonites cf. B. balatonicus, Kellnerites samneuensis, Danubites kansa, Hollandites sp. and Acrocordiceras sp. (Ahmad Rosli \& Mohd Shafeea, 2010; Figure 8). Meanwhile, fossils of bivalve include Costatoria pahangensis, $C$. malayensis, Neoschizodus ovatus, N. (Leviatus) elongatus, Langsonella elongata, Hoernesia magnesimma and Entolium descites (Ahmad Rosli, 2010). All these molluscan fossils represent of Middle Anisian of Middle Triassic in age.

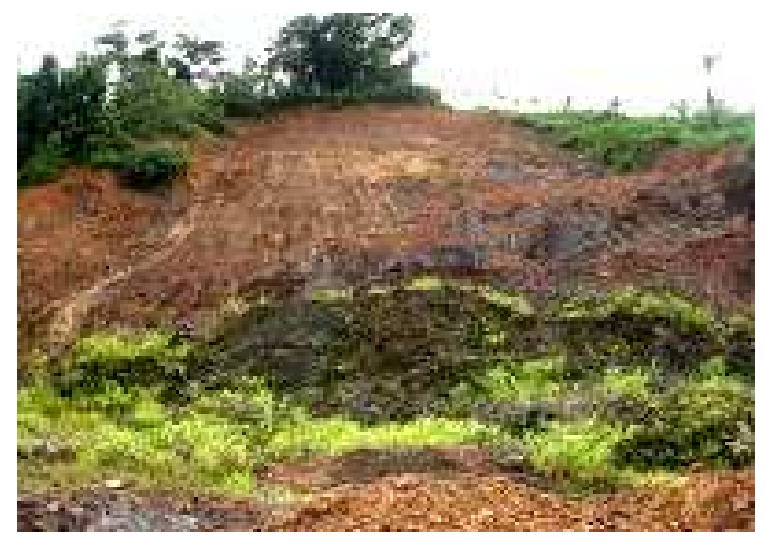

Fig. 5 Fossil-containing outcrop in Fossil Site-1 (QZ467), Aring area.

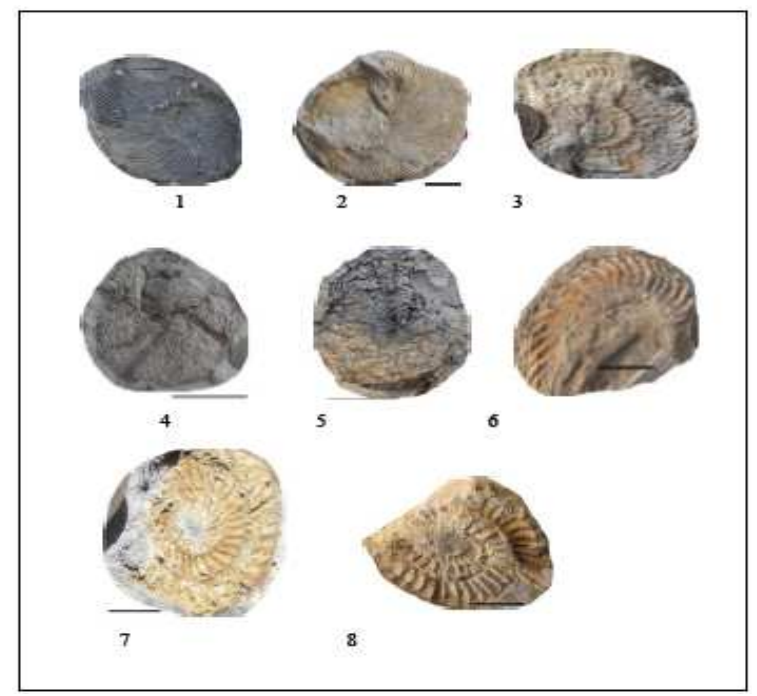

Fig. 6 A large assemblage of ammonoid fossils were discovered from the outcrop of sedimentary rocks at Fossil Site-1 (QZ467). [Scale bar represents $1 \mathrm{~cm}$.$] 1) Frankites regoledanus (Mojsisovics), 2) Frankites apertus$ (Mojsisovics), 3) Protrachyceras costulatum Mansuy, 4) Joannites sp., 5) Megaphyllites jarbas Mojsisovics, 6) Anolcites sp., 7) Clionitites sp., 8) Celtites epolensis Mojsisovics (after Ahmad Rosli \& Mohd Shafeea, 2010). 


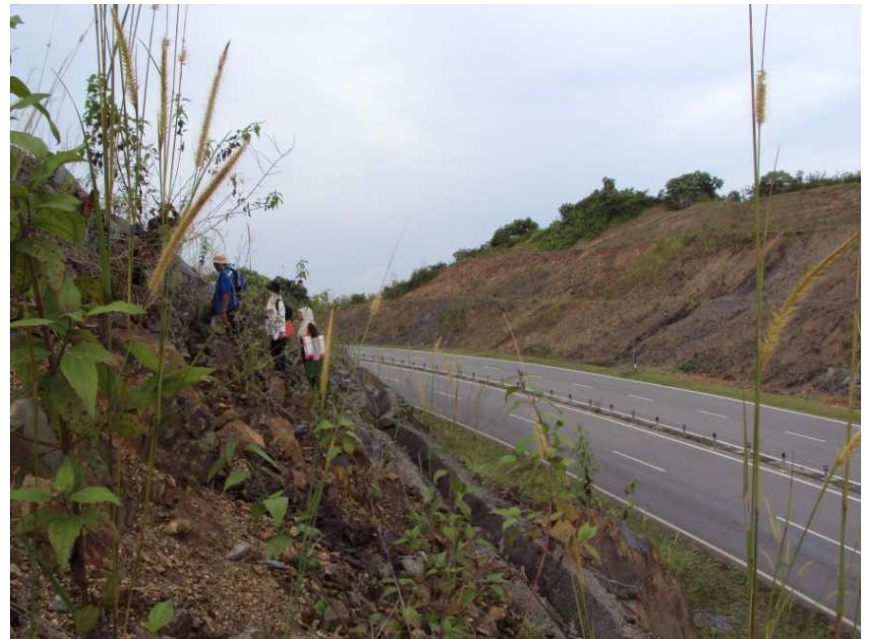

Fig. 7 Fossil-containing outcrop in Fossil Site-2 (QZ480), Aring area.

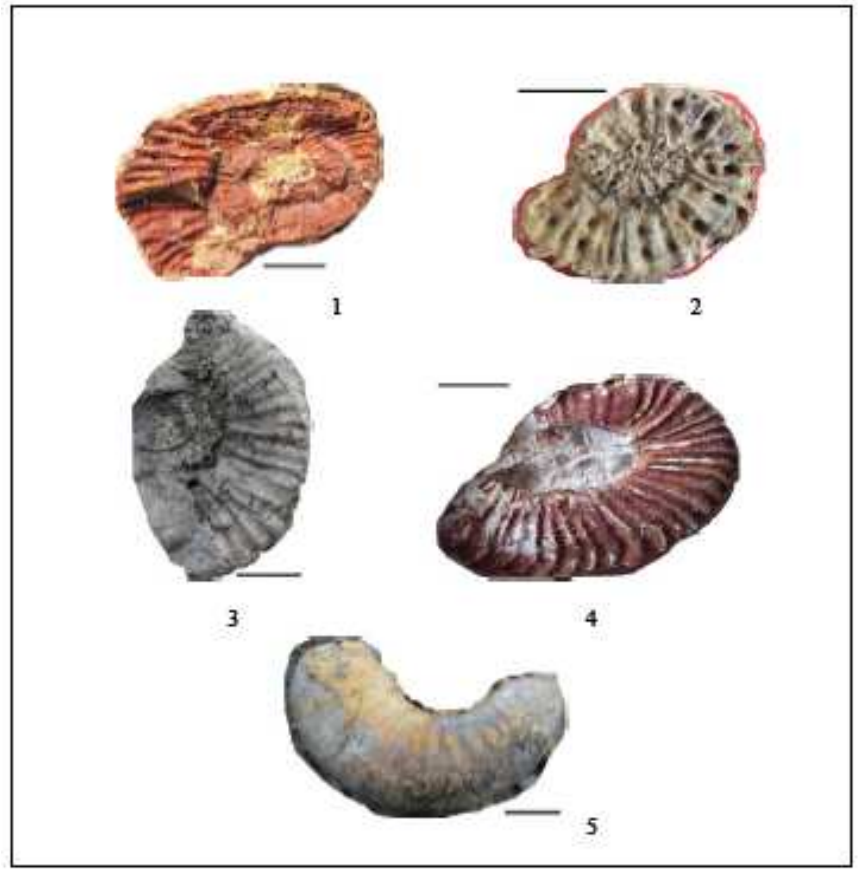

Fig. 8 Fossils of ammonoid species from Fossil Site-2 (QZ480): 1) Balatonites cf. B. balatonicus, 2) Kellnerites samneuensis, 3) Danubites kansa, 4) Acrocordiceras sp. and 5) Hollandites sp. (after Ahmad Rosli \& Mohd Shafeea, 2010).

\section{THREATS TO FOSSIL SITES IN ARING AREA}

Like the treaths to fossil sites in other countries (for example fossil sites in New Zealand as stated by Hayward, 2009), there are also some threats to fossils sites in Aring area that need to be handled as follow:

\section{A. Development}

Fossil sites in Aring can be lost through some developments such as the retaining walls and concrete or grass seed spraying of exposures. All the strata in the fossil sites are now excellently exposed and there is so far no any problem if the fossil-containg outcrops are left open without any retaining wall and concrete or grass seeding. The exposures will make fossils are accessible to visitors.

\section{B. Collecting}

While recognising that collecting often "saves" our fossil heritage, this needs to be balanced against the need to protect in situ values. Fossils in Aring area are on public lands that are not in a reserve, so they are generally available for anyone to collect and own. However, various fossils in their original position in their original rocks can be lost by uncontrolled collecting activities.

\section{Neglect}

Despite its easy accessibility, fossil sites in Aring are now still not managed well and not many people know these sites. Only some local paleontologists and geologists come to these sites to study the fossils but infrequently. Other than them, Geoscience students of UMK visits the sites every year for the fieldwork of subject Paleontology (Figure 9). Between these visits many exposures become overgrown or weathered through neglect.

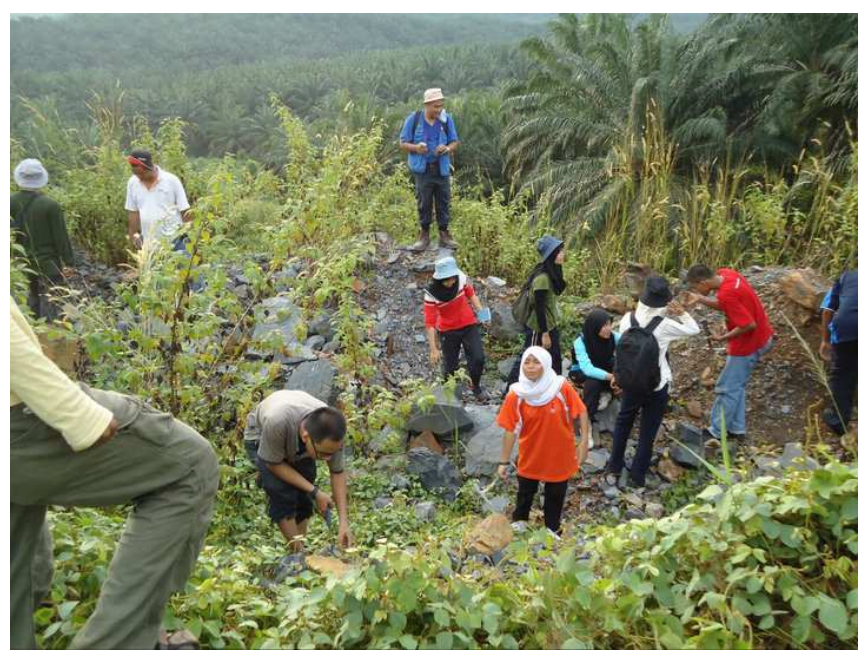

Fig. 9 Geoscience students of UMK visit Aring area every year to find and study fossils directly in the fossil sites.

\section{CONSERVATION OF Fossils And Fossil Sites: A Proposal To ARING AREA}

UMK and JMG Kelantan through their joint research and collaboration will propose some initiatives in order to protect and conserve the fossils and fossil sites in Aring area. In addition, the initiatives aims are also to allow scientific study, to permit public educational and recreational activities, to improve the appearance of Aring area, as well as to empower local community for their benefits.

In Malaysia, so far, fossils are only on display for general public at the Geological Museum in Ipoh, Perak and in the departments of geology in the universities. However, sometime there is no point in removing good fossils from paleontological sites to the museum or universities. Therefore, it is important to conserve fossils in their original positions in fossil sites mainly for the scientific purposes.

The basic necessities of paleontological site conservation are the ongoing identification and scientific assessment of sites with the help of reputable scientists and producing the correct responses to threatening developments to the sites (Lee, 1992). According to Lipps (2009), small local sites to national or international areas that protect paleontological 
treasures are essential, if we are to preserve and understand the history of life on Earth and to provide materials for scientific research now and in the future. This includes the protection of fossil-bearing strata. Many paleontologicallyimportant field sites are already protected and conserved in a variety of ways, from international to national to local and even private levels. Many countries have recognized their paleontologic heritage by passing legislation against fossil collecting and some have preserved the best sites as parks or reserves. Likewise state, province and other local jurisdictions have also recognized the value of fossil deposits by protecting and conserving them in various ways. At the international level, UNESCO's World Heritage program, currently including 890 properties with cultural or natural heritage values, has recognized many paleontologically valuable sites. UNESCO's Geoparks Network with currently 58 Geoparks all over the world also concerns with paleontology and some fossil sites.

Protection of paleontological field resources varies enormously from country to country and even within single countries. To date, countries (such as Ethiopia, Australia, China, United States, Canada, New Zealand, Mexico, France, and others) have moved to protect the scientific values of such areas, often as tourist attractions. Some countries have laws against disturbing any fossil site or fossils.

\section{A. A Proposed "Aring Field Museum of Paleontology"}

Paleontologists and geologists in Malaysia generally and they are from UMK and JMG Kelantan especially, should play important roles in leading the effort to conserve the fossil heritage and fossils sites in Aring area in order to provide guidance on their preservation and conservation. Although these fossil sites are unlikely to reach iconic World Heritage or Paleopark status, they do provide a window into the unique evolutionary history of Peninsular Malaysia. One of initiatives to conserve the fossils and fossil sites in Aring area which can be suggested by UMK and JMG Kelantan is by setting up a field museum of paleontology in the area.

A paleontological field museum is an outdoor museum where fossils are protected and conserved in the location. In this context, a fossil site is developed into an in-place museum. Different with "traditional" indoor museums, a field museum is more attractive and will provide exhibits showing various fossils in their original positions in their original rocks. All fossils are protected within this field museum and permits are required for collection in some but not in others. Many important fossils will enjoy protection from this field museum. The field museum will play very important roles not only to conserve fossils, but also to educate public about the values of fossils, to instill a desire to protect these valuable resources, and to act as the center for collaboration in research and conservation of fossils.

Why field museum and not indoor museum as usual? According to Lipps (2009), field sites provide other data that cannot be or is not commonly preserved in (indoor) museums, such as sedimentary rock characteristics and structures, assosiated trace fossils, data from contiguous layers, and so on.

Some countries have successfully built their field museum of paleontology for the protection and conservation of fossils and fossil sites, such as Wadi Al-Hitan (Whale Valley) in
Egypt, Phu Kum Khao Dinosaur Field Museum in Thailand, Dinosaur Ridge in USA and a field museum in the Wolonggang, China (Figure 10).
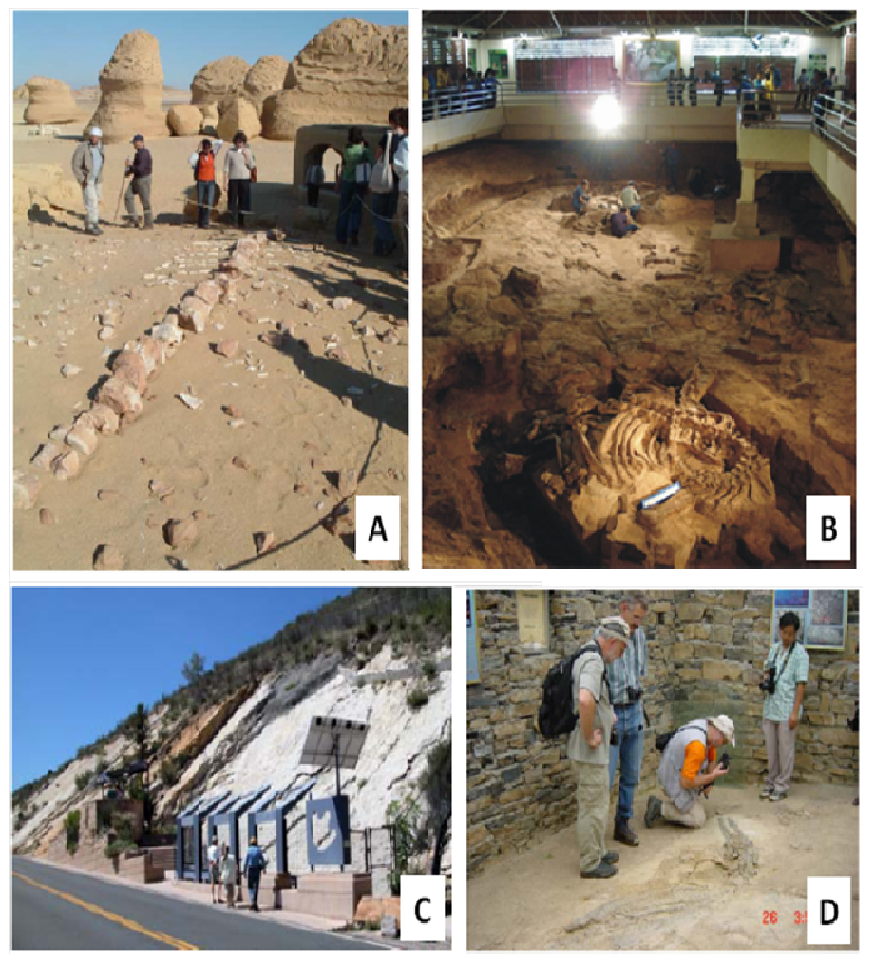

Fig 10. Some examples of succesful field museum of paleontology in some countries: (A). Wadi Al-Hitan (Whale Valley) in Western Desert of Egypt. It displays the remains of Late Eocene archeocete whales and other fossils, and protect the site for further research (Lipps, 2009); (B). Phu Kum Khao Dinosaur Field Museum in Thailand. Dinosaur bones found and conserved in situ (Boonchai et.al., 2009); (C). Dinosaur Ridge, near Denver, Colorado, USA, is a locally-operated site protecting a series of dinosaur tracks, mangrove impressions, and invertebrate trace fossils (Lipps, 2009); and (D). A field museum displays a nearly complete skeleton marine reptile and crinoid colonies preserved on the black shale and mudstone bedding planes in the Wolonggang, China (Wang et.al., 2009).

Based on the fossils discovered, the proposed Aring Field Museum of Paleontology will be expected to provide an interesting view of the life some $200-250$ million years ago during the Triassic. The field museum will attract wide attention. More and more paleontologists, geologists and researchers will come to visit the field museum for scientific study of the taxonomy, evolution, paleoecology, paleobiogeography of fossils, and their sedimentary rocks and taphonomic processes as well as for common people to learn and enjoy the exceptional fossils and their preservation in the rocks. In the field museum, it is hoped that a docent program provides on situ guided tours and discussion of the fossils and rocks.

This field museum will provide paleontological values for all visitors with the opportunity to participate by camping, lectures, hiking and research through the area. This area should be protected by involving many parties including of authorities, paleontologists / geologists / geoscientists, academic institutions, organizations and local people that work towards the conservation and the good use of it. This field museum also as a symbol to encourage local people to 
protect paleontological sites as interesting and educational, as well as valuable, so that they are not degraded.

The field museum should has adequate and acceptable space to allow fossils to be exposed well to the visitors. Meanwhile, the appearance of Aring area will be developed better than just a plantation area. This field museum will be arranged to have a system that will be supported by local people who have a vested interest in it. The people will assist the paleontologists/geologists to provide the guidance and oversight for activities by tourists that visit the area. Some facilities and infrastuctures also should be designed and built for the comfort of visitors.

\section{DISCUSSION AND CONCLUSIONS}

Our interest in the protection and conservation of fossils and fossil sites was inspired by our discovery of fossils in Aring area a few years ago. Fossil is a rare geological resource and non-renewable resources, so it is a pride to be able to discover any fossil. Aring is a unique area in Kelantan, because it is so far the one and only area in the state that contains numerous and various small-sized invertebrate fossils. So, we think that we need to expose this area as an important paleontological site in Malaysia.

Aring area in Kelantan, Malaysia contains numerous and various fossils, mainly from the Triassic. Paleontologists, geologists and researchers have been coming to the area to study the fossils and geological data of the area. Most kinds of fossils are belonged to the phylum Mollusc, along with phylum Brachiopods found in thin layers of tuffaceous mudstones, indicated as part of Telong Formation. Fossil records so far from these two fossil sites (Fossil Site-1 and Fossil Site-2) are mostly from ammonoid and bivalve species. Ammonoid species found in these two sites include Frankites regoledanus (Mojsisovics), Frankites apertus (Mojsisovics), Protrachyceras costulatum Mansuy, Joannites sp., Megaphyllites jarbas Mojsisovics, Anolcites sp., Clionitites sp., Celtites epolensis Mojsisovics, Balatonites cf. B. balatonicus, Kellnerites samneuensis, Danubites kansa, Hollandites sp. and Acrocordiceras sp. Bivalve fossils from these sites are Posidonia kedahensis Kobayashi, Posidonia kedahensis Wissman, Daonella pahangensis Kobayashi, Costatoria pahangensis, $C$. malayensis, Neoschizodus ovatus, N. (Leviatus) elongatus, Langsonella elongata, Hoernesia magnesimma and Entolium descites (as mentioned above).

As explained above, fossil occurrences in Aring area are endangered by some threats i.e. development, collecting and neglect. Paleontologists will have to think creatively to achieve proper protection and conservation of the fossils and fossil sites in the area. UMK as a public institution of higher education in the state of Kelantan, along with JMG Kelantan as a government department which manages all about minerals and geoscience (including paleontology) in the state, are responsible to protect and conserve this fossil heritage within the state territory.
It should be considered carefully by local paleontologists for the preservation and conservation of these resources. Those sites that are deemed worthy of preservation should be designated a field museum of paleontology. The establishment of a field museum in Aring area will increase awareness of fossils, increase government and public interest, and expand tourism and recreation beneficial to the development of the area.

\section{ACKNOWLEDGMENT}

We would like to thank UMK for giving us a fund to run this small project under the short-term grant scheme no. R/SGJP/A03.00/00642A.001/2011/ 000061. We also appreciate some staff of JMG Kelantan for their assistance.

\section{REFERENCES}

[1] Ahmad Rosli Othman \& Mohd Shafeea Leman. (2008). The discovery of Triassic Ladinian- Carnian ammonoid assemblage from Aring, Gua Musang, Kelantan. Paperwork of JMG Conference 2008, Kota Bharu, Kelantan (in press).

[2] Ahmad Rosli Othman \& Mohd Shafeea Leman. (2009). The discovery of Middle Triassic Bivalve Daonella pahangensis Kobayashi from Aring, Kelantan. Geological Notes of Warta Geologi (ISSN 0126-5539), Vol. 35, No. 3, Jul-Sep, pp. 111-114. Geological Society of Malaysia.

[3] Ahmad Rosli Othman \& Mohd Shafeea Leman. (2010). Middle Triassic ammonoid fossils from Aring, Kelantan, Malaysia. Bulletin of the Geological Society of Malaysia 56, pp. 53- 59.

[4] Ahmad Rosli Othman. (2010). Guide Book of Paleontological Field Work (JMG Kelantan and UMK). Department of Minerals and Geoscience Malaysia Kelantan. Unpublished.

[5] Aw, P. C. (1990). Geology and Mineral Resources of the Sungai Aring Area, Kelantan Darul Naim. Geological Survey of Malaysia, District Memoir 21, 116 p.

[6] Boonchai, N., Grote, P.J. and Jintasakul, P. (2009). Paleontological parks and museums and prominent fossil sites in Thailand and their importance in the conservation of fossils. Notebooks on Geology - Book 2009/03, Chapter 7 [http://paleopolis.rediris.es/cg/ CG2009_BOOK_03/CG2009_BOOK_03_Chapter07.pdf].

[7] Hayward, B.W. (2009). Protecting fossil sites in New Zealand. Notebooks on Geology - Book 2009/03, Chapter 5

[8] Kamal Roslan Mohamed. (2006). Stratigraphy of Peninsular Malaysia: Geology of the Southern Kelantan (Lecture Note). National University of Malaysia. Unpublished.

[9] Lee, C. P. (1992). Fossil Localities in Malaysia: Their Conservation and Significance (Background paper). Malaysian National Conservation Strategy. Economic Planning Unit, Kuala Lumpur.

[10] Lipps, J.H. (2009). PaleoParks: Our paleontological heritage protected and conserved in the field worldwide. Notebooks on Geology - $\quad$ Book 2009/03, Chapter 1 [http://paleopolis.rediris.es/cg/CG2009_BOOK_03/CG2009_BOOK 03_Chapter01.pdf].

[11] Wang, X., Chen, X., Wang, C. and Cheng, L. (2009). The Triassic Guanling fossil Group - A key GeoPark from a barren mountain, Guizhou Province, China. Notebooks on Geology - Book 2009/03, Chapter 2 [http://paleopolis.rediris.es/cg/CG2009_BOOK_ 03/ CG2009_BOOK_03_Chapter02.pdf].

[12] Zakaria Hussain, Mohammad Roston Zakaria and Mohd Shafeea Leman. (2008). Geoheritage of Malaysia. In: Mohd Shafeea Leman, Anthony Reedman and Chen Shick Pei (2008). Geoheritage of East and South East Asia. LESTARI and CCOP 